(C) Copyright 2020: Editum. Servicio de Publicaciones de la Universidad de Murcia. Murcia (Spain) ISSN print edition: 0212-9728. ISSN on line edition (http://revistas.um.es/analesps): 1695-2294.

On line edition License Creative Commons 4.0: BY-NC-ND

\title{
Cognitive Flexibility and Mental Well-Being in Turkish Adolescents: The Mediating Role of Academic, Social and Emotional Self-Efficacy
}

\author{
Ayşe Sibel Demirtaş
}

Alanya Alaaddin Keykubat University (Turkey)

\begin{abstract}
Título: Flexibilidad cognitiva y bienestar mental en adolescentes turcos: El papel mediador de la autoeficacia académica, social y emocional.

Resumen: La adolescencia es una etapa crítica de crecimiento y desarrollo en el ciclo de vida de un individuo. Debido a la importancia del éxito en el desarrollo durante esta etapa, con implicaciones del desarrollo adulto y la salud mental positiva, el presente estudio tiene como objetivo examinar los roles predictores de la flexibilidad cognitiva y la autoeficacia en el bienestar mental de los adolescentes turcos. Además, dado que se considera que la asociación entre la flexibilidad cognitiva y la autoeficacia tiene efectos cruciales en el bienestar mental de los adolescentes, se suponía que la autoeficacia académica, social y emocional podría mediar la relación entre la flexibilidad cognitiva y el bienestar mental. . Los participantes de la investigación están compuestos por 192 mujeres (49 \%) y 200 hombres (51\%), Un total de 392 estudiantes de secundaria que asistían a cuatro escuelas secundarias diferentes se inscribieron en los grados 9-12, en una ciudad de Turquía. El Inventario de Flexibilidad Cognitiva, la Escala de Autoeficacia para Niños y la Escala de Bienestar Mental Warwick-Edinburgh se aplicaron en la recolección de datos. Los resultados mostraron que la flexibilidad cognitiva se correlacionó positivamente con las subdimensiones de autoeficacia y bienestar mental. Además, las subdimensiones de autoeficacia se correlacionan positivamente con el bienestar mental. Los resultados del modelo mediacional indicaron que la autoeficacia académica, social y emocional sirvió para mediar la relación entre la flexibilidad cognitiva y el bienestar mental. Los resultados de la investigación se discutieron a la luz de la literatura y se propusieron algunas sugerencias para expertos e investigadores en salud mental. El Inventario de Flexibilidad Cognitiva, la Escala de Autoeficacia para Niños y la Escala de Bienestar Mental Warwick-Edinburgh se aplicaron en la recolección de datos. Los resultados mostraron que la flexibilidad cognitiva se correlacionó positivamente con las subdimensiones de autoeficacia y bienestar mental. Además, las subdimensiones de autoeficacia se correlacionan positivamente con el bienestar mental. Los resultados del modelo mediacional indicaron que la autoeficacia académica, social y emocional sirvió para mediar la relación entre la flexibilidad cognitiva y el bienestar mental. Los resultados de la investigación se discutieron a la luz de la literatura y se propusieron algunas sugerencias para expertos e investigadores en salud mental.
\end{abstract}

Palabras clave: Flexibilidad cognitiva; Autoeficacia; Bienestar mental; Adolescentes; Mediación múltiple paralela.

\section{Introduction}

\section{Background and Aim}

Interest in well-being research has increased dramatically as the research investigating the individual differences and psychological factors that can promote well-being have valuable contribution on quality of people's lives. Recent conceptuality of well-being have specified in two domains that have emerged from the "hedonic" and "eudaimonic" philo-

* Correspondence address [Dirección para correspondencia]: Ayşe Sibel Demirtaş, Ph.D., Alanya Alaaddin Keykubat University, Faculty of Education, Department of Psychological Counseling and Guidance, Alanya, Antalya (Turkey). E-mail: asibeldemirtas@gmail.com

(Article received: 7-7-2018; revised: 22-10-2018; accepted: 27-6-2019)

\begin{abstract}
Adolescence is a critical stage of growth and development in life-cycle of an individual. Because of the importance of developmental success during this stage, with implications of adult development and positive mental health, the current study aims to examine the predictor roles of cognitive flexibility and self-efficacy on mental well-being of Turkish adolescents. Moreover, as the association between cognitive flexibility and self-efficacy are considered to have crucial effects on adolescents' mental well-being, it was supposed that academic, social and emotional selfefficacy could mediate the relation between cognitive flexibility and mental well-being. The participants of the research are comprised of 192 females $(49 \%)$ and 200 males (51\%), a total of 392 high school students who were attending four different high schools enrolled in grades $9-12$, in a city of Turkey. Cognitive Flexibility Inventory, The Self-Efficacy Scale for Children and Warwick-Edinburgh Mental Well-Being Scale were applied in data collection. The results showed that cognitive flexibility positively correlated with sub-dimensions of self-efficacy and mental well-being. Also, sub-dimensions of self-efficacy positively correlated with mental wellbeing. Findings from the mediational model indicated that academic, social and emotional self-efficacy served to mediate the relationship between cognitive flexibility and mental well-being. Research findings were discussed in the light of the literature and some suggestions were proposed for mental health experts and researchers.

Keywords: Cognitive flexibility; Self-efficacy; Mental well-being; Adolescents; Parallel multiple mediation.
\end{abstract}

sophical views. "Hedonic well-being", also known as subjective well-being, is defined as positive emotions and mental experiences that occur frequently, negative emotions and mood rarely experienced and a high level of life satisfaction (Diener, 1984). Eudaimonic well-being, which is conceptualized by the psychological well-being model of Ryff (1989), explains eudaimonia, which comprises "eu" (good) and "daimon" (spirit) words and means "happiness", "welfare", "flourishing" and focuses on how individuals struggle to demonstrate full functionality and to gain awareness of their unique talents.

Adolescence a critical stage of growth and development that serves as the bridge between childhood and adulthood. This period involves multiple life-changes and transitions in terms of biologically, cognitively, emotionally, and socially. An adolescent has some developmental tasks such as devel- 
oping an individual identity and self-respect, adapting to new intellectual capabilities and demands of the society, internalising a personal value system and preparing for adult roles, establishing vocational goals and gaining emotional and psychological independency from parents (Cicchetti \& Rogosch, 2002). As a result of these changes and tasks, the adolescents experience increased demands and stress. On the other hand, some empirical studies indicated that adolescence should not be identified as a stage of emotional confusion, as the greater number of adolescents succeed this transition without affected negatively (Bandura, 1997; Offer \& Schonert-Reichl, 1992). Positive psychology approach emphasizes the strengths of person, maximizes human functionality for the discovery and promotion of factors affecting the development of individuals and communities (Sheldon, Fredrickson, Rathunde, Csikszentmihalyi, \& Haidt, 2000). From positive psychology point of view, adolescence is a developmental period of having opportunities and challenges. Therefore, it is important to find out what strengths of adolescents encourage them to overcome the challenges they face in this stage.

Well-being literature has provided considerable evidence regarding the correlates of this positive construct in adolescents. Latest research has revealed that well-being of adoles- cents has been associated with life of meaning, social support, emotion regulation and psychological needs satisfaction (Li \& Feng, 2018; Morrish, Rickard, Chin \& Vella-Brodrick, 2018; Yang, Li, Fu \& Kou, 2017; You, Lim \& Kim, 2018). Furthermore, previous studies on Turkish adolescents have demonstrated the association of well-being with various variables such as optimism, self-esteem, interpersonal competence, social acceptance, social support and personality traits (Arslan, 2018; Baytemir, 2016; Çakar \& Tagay; 2015; Duy \& Yıldız, 2017; Eryılmaz \& Öğülmüş, 2010). These findings suggest that the research concerning the contributing factors on well-being has important outcomes in understanding the positive youth development. Although there are many studies on subjective well-being, the research in mental wellbeing remains limited in Turkey. Therefore, the present study aims to investigate the predictor roles of cognitive flexibility and self-efficacy on mental well-being of Turkish adolescents. Moreover, as the association between cognitive flexibility and self-efficacy are considered to have crucial effects on adolescents' mental well-being, it was supposed that academic, social and emotional self-efficacy could mediate the relation between cognitive flexibility and mental wellbeing (Figure 1).

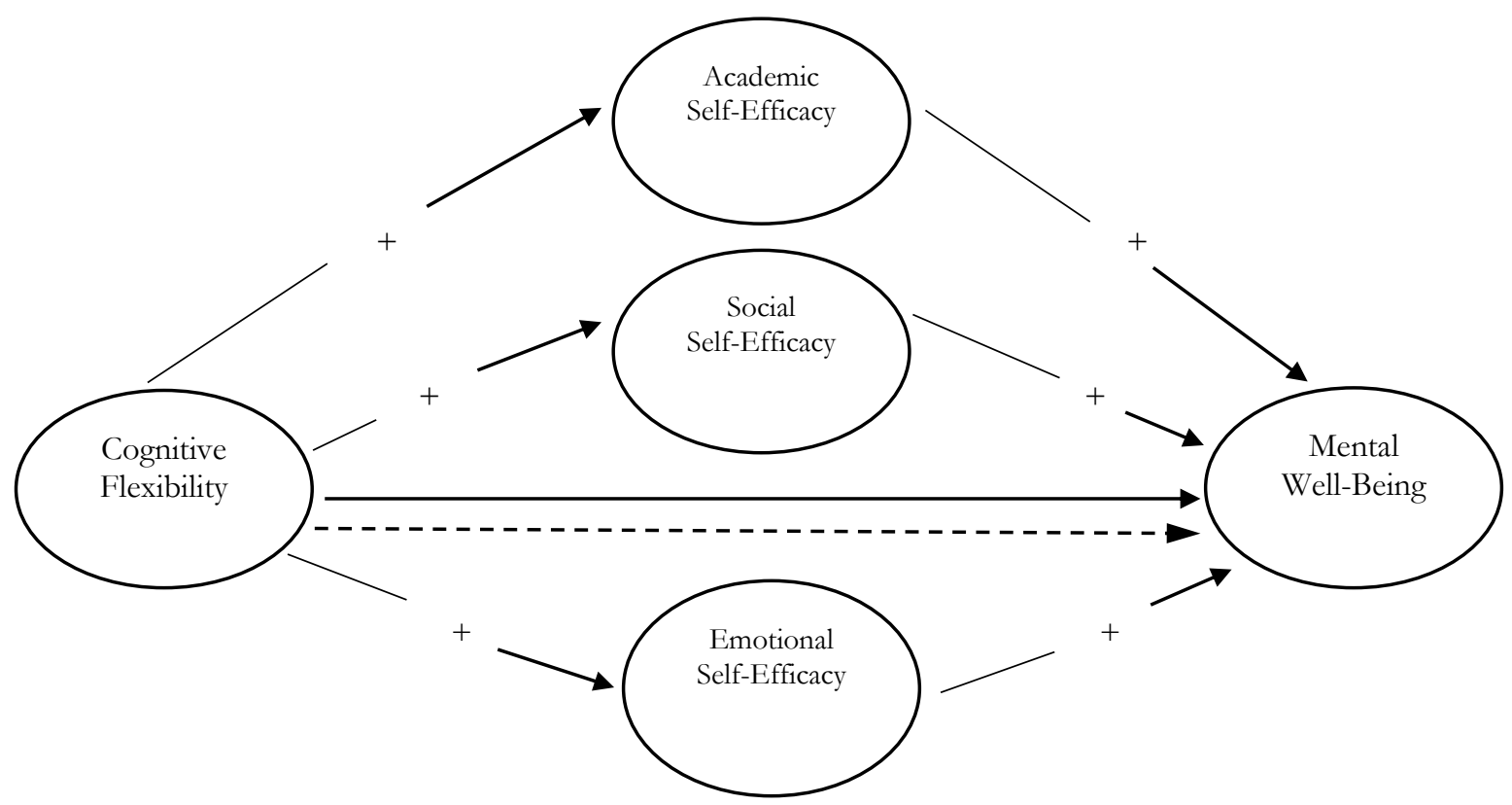

Figure 1. Hypothesized Model.

\section{Mental Well-Being}

The term "mental well-being" is generally used in literature interchangeably with the term "positive mental health" (Tennat et al., 2007). Although there is an argument about precise explanations of both well-being and mental wellbeing (Huppert \& Whittington, 2003; Keyes, 2005) there is a wide consensus that mental well-being is more than lack of mental illness and that it comprises both hedonic (subjective well-being) and eudaimonic (psychological well-being) dimensions (Ryan \& Deci, 2001). Warwick-Edinburgh Mental Well-Being Scale (WEMWBS) was developed by Tennant et al. (2007) in order to apprehend a broad definition of wellbeing involving these dimensions and increase attention that getting an extensive understanding of mental well-being levels. The WEMWBS includes both hedonic elements of po- 
sitive mental well-being (e.g., "I’ve been feeling cheerful", or "I have been feeling relaxed") and eudaimonic elements of positive mental well-being (e.g., "I've had energy to spare", or "I've been thinking clearly") (McKay \& Andretta, 2017). Prior studies have shown that mental well-being is associated with self-compassion, perceived social support, emotional support, hope and constructive thinking (Bloom, Stewart, Johnston, Banks, \& Fobair, 2001; Demirtaş, Baytemir, \& Güllü, 2018; Imtiaz \& Kamal, 2016; Khalled \& Jabr, 2016).

Mental well-being research is attracting increasing attention world-wide, because it has significant implications not only for psychological functioning but also for health and social outcomes (Stewart-Brown et al., 2009). The construct of mental well-being is also an important health indicator of adolescents. For instance, McKay and Andretta (2017) found, on a sample composed by 2721 high school students in Scotland and Northern Ireland, that mental well-being had a positive relationship with self-rated health and a negative association with psychosomatic symptomatology. Similarly, Lopez et al. (2013) reported in their research on college sample that positive affect, life satisfaction, and overall health had positive high correlations with mental well-being. Other researchers have confirmed that individuals with higher mental well-being show lower risks for physical and mental disorders and lower use of health services (Keyes 2005; Nordentoft, 2007). Mental well-being provides individuals to gain awareness about their capabilities, overcome with the life stress, work in a productive and fruitfull way, and make contributions to their community. It includes not only major outcomes for the benefit of health and social issues but also the capacity for satisfactory and permanent relationships (Ryan \& Deci, 2001; Tennant et al., 2007).

\section{Cognitive Flexibility}

The other construct that is related to mental well-being is cognitive flexibility which refers to a person's "(a) awareness that in any given situation there are options and alternatives available, (b) willingness to be flexible and adapt to the situation, and (c) self-efficacy in being flexible" (Martin \& Rubin, 1995 , p. 623). It is the ability to alter thoughts in terms of changeable environment conditions (Dennis \& Vander Wal, 2010). Other researchers conceptualize cognitive flexibility as the extent to which individuals think and deal with different views in flexible ways (De Dreu, Baas, \& Nijstad, 2008). Cognitively flexible individuals are eager to encounter unfamiliar situations, to try new ways of communication and to adjust behaviours to meet contextual needs. Prior studies have demonstrated that increased levels of cognitive flexibility is related to more extroverted, more self-controlled and more openness for improvement (Bilgin, 2017) and more possible to use problem focused coping in adolescents (Zhang, 2011). Flexibility has been found to have an association with various measures of psychological outcomes in the meta-analysis of 32 studies (Hayes, Luoma, Bond, Masuda, \& Lillis, 2006). Lin (2013) found, on a sample composed by
770 college students, that cognitive flexibility had positive impact on openness to change and academic performance. Cognitive flexibility has also been demonstrated to have negative association with parent-child conflicts which means cognitively flexible children create more alternative solutions to cope with conflicts between themselves and their parents (Ahn, Kim \& Park, 2008). In another study with college students, cognitive flexibility has been positively related to better psychological health, involving decreased depression, anxiety, and distress (Kato, 2012). Furthermore, it was reported in literature that cognitive flexibility is the predictor of school adaptation (Bing, 2011), life satisfaction (Çikrıkci, 2018) and happiness (Asıc1 \& İkiz, 2015). These results suggest that cognitive flexibility enables greater success in achieving desired goals (Tamir, 2009) and reduce the impact of negative experiences (Hirt, Devers, McCrea, 2008) by providing individuals to create ideas, take into consideration alternative views in order to adapt to changes in the environment (Johnson, 2016).

\section{Self-Efficacy}

Based on the above explanations, this study suggests another psychological construct "self-efficacy" that may explain the mechanism linking cognitive flexibility and mental well-being. Self-efficacy which is an essential concept of "Social-Cognitive Theory" refers to "people's judgments of their capabilities to organize and execute courses of action required to attain designated types of performance" (Bandura, 1986, p. 391). Social-cognitive perspective on personality (Bandura, 1977, 1997; Mischel \& Shoda, 1995) emphasizes the cognitive-affective processes in the development of personality and on that premise of these processes, people generate beliefs about themselves and their relation to the social environment. Considering an important aspect of the selfsystem, self-efficacy involves "self-regulation of cognition processes, motivation, and affective and physiological states" (Bandura, 1997, p. 30). Self-efficacy, which has an impact on how people feel, think, motivate themselves and behave, contribute to well-being and healthy development throughout the lifespan (Bandura, 1994; Phillips \& Zimmerman, 1990). Self-efficacy is a multidimensional construct that consistent with the domain of needs (Zimmerman, 2000), therefore must be assessed at a level that is specific to the need (Bandura, 1999; Pajares, 1996). Academic self-efficacy refers to individuals' belief that they can achieve the academic works successfully (Bandura, 1997). Social self-efficacy, which is essential for social behaviour, has been defined as an awareness of the capabilities that allow the individual to attain social interactions, dealing with social situations and social conflicts (Bandura, 1999). Considering as an important factor in regarding good mental health, emotional selfefficacy refers to individuals' capability to understand and manage their emotional reactions (Bandura, Pastorelli, Barbaranelli, \& Caprara, 1999).

Self-efficacy is a vital component of cognitive flexibility. 
According to Martin and Rubin's (1995) definition of the construct, cognitively flexible individuals are not only aware of alternatives and willing to adjust to the situation but also have self-efficacy beliefs. Cognitively flexible people have self-confident in their own capacity to behave in an effective way (Bandura, 1977). A recent study by Akçay-Özcan and Kiran-Esen (2016) concluded, on a sample composed by 1035 Turkish adolescents, that high cognitive flexibility of adolescents indicates high academic, social, emotional and general self-efficacy. These findings appear consistent with the characteristics of individuals with high cognitive flexibility view themselves more competent than those who are not flexible.

Self-efficacy is also considered as an essential contributing factor on adolescents' well-being. Adolescence is a crucial period that involves multiple life-changes and transitions (Cicchetti \& Rogosch, 2002). The achievement of the management with the risks and challenges in this period depends on the strength of adolescents' self-efficacy beliefs (Bandura et al., 1999). Research has provided evidence for the contributing role of self-efficacy on adolescents' well-being. For example, Cicognani (2011) reported in his research that selfefficacy helped the adolescents endure minor stressors and enhanced psychological well-being and social support. This notion has been also supported by Caprara, Steca, Gerbino, Pacielloi and Vecchio (2006) who stated that perceived selfefficacy foster positive expectations about the future, to retain a high self-concept, to perceive life satisfaction and to experience more positive emotions. Other researchers have confirmed that adolescents' self-efficacy beliefs have positive effects on psychological well-being (Moeini et al., 2008; Tommasi et al., 2018), subjective well-being (Ma, Zeng \& Ye, 2015; Yap \& Baharudin, 2016) and quality of life (Taş, Öztürk-Çopur, Ünlü, Tüzün, \& Özcebe, 2017). Telef and Ergün (2013) found, on sample composed by 311 Turkish adolescents, that academic, social, and emotional self-efficacy beliefs predicted their subjective well-being. Self-efficacy has also been found in negative correlation with symptoms of anxiety disorders and depression (Hermann \& Betz, 2004; Muris, 2002; Telef \& Karaca, 2011) and destructive social behaviour (Caprara, Regalia \& Bandura, 2002) in adolescents. Furthermore, adolescents' self-efficacy beliefs have found to be an indicator of the variables such as academic functioning (Bandura, Barbaranelli, Caprara, \& Pastorelli, 1996; Mc Geown et al., 2014; Meyer \& Kim, 2000) and psychosocial functioning (Bandura, Caprara, Barbaranelli, Gerbino, \& Pastorelli, 2003) that are closely associated with their well-being.

\section{The Current Study}

Adolescence is a critical stage in an individual's life. It is not only a period of accelerated growth and change but also a transition period between childhood and adulthood. In previous literature, cognitive flexibility and self-efficacy have been reported to have a significant, positive relationship with well-being of adolescents. However, no prior studies have examined the association of mental well-being with cognitive flexibility and self-efficacy. Because of the importance of developmental success during this stage, with implications of adult development and positive mental health, the current research was designed to examine the parallel multiple mediation of self-efficacy (academic-social-emotional) in the relationship between cognitive flexibility and mental well-being in adolescents (Figure 1). The examination of contributing roles of cognitive flexibility and self-efficacy on mental wellbeing is an important issue in adolescent well-being research. The present study is considered to contribute considerably to adolescents' well-being in literature.

\section{Method}

\section{Research Design}

Correlational research design was used in the current research. Correlational research is used to examine the relationships between variables without any attempt to influence them (Fraenkel, Wallen, \& Hyun, 2012). The relationships between cognitive flexibility (predictor variable), academic self-efficacy, social self-efficacy, emotional self-efficacy (mediator variable) and mental well-being (outcome variable) were examined through mediation analysis.

\section{Participants and Procedure}

A total of 392 high school students [192 females (\%49), 200 males (\%51) aged $14-18$ years, median age 15 years] participated in the study. Convenient sampling was used for the participants of the research. Cohen, Manion and Marrison (2011) stated that convenience sampling refers to "choosing the nearest individuals to serve as respondents and continuing that process until the required sample size has been obtained or those who happen to be available and accessible at the time" (p. 155). The participants of the current study were attending four different high schools enrolled in grades 9-12

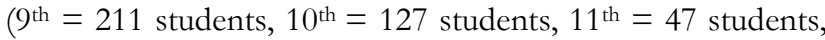
$12^{\text {th }}=7$ students) in Antalya, Turkey. The schools were located in Alanya which is one of the touristic town on the southern coast of Turkey. In Turkish schooling system, there are high school types which offer different kinds of education. One of the school type in which the participants of the research attending is Anatolian high school that admits their students according to high nationwide standardized test scores. The other school type is Imam Hatip high school that aims train personnel for religious services in society. The others are two vocational high schools (technical and multiprogram high schools) which intends to prepare students for a certain kind of profession. In accordance with the ethical principles of research with students, permission was obtained from Ministry of Education. All students voluntarily participated in the research (not given an extra credit or compensation) in classroom settings at their schools. It was also stated that the names should not be written on the scale and the 
study serves scientific purposes and all the information is private. The gathering of the data lasted approximately 20 minutes.

\section{Data Collection Tools}

\section{Cognitive Flexibility Inventory (CFI)}

CFI was developed by Dennis and Vander Wal (2010) in order to measure the cognitive flexibility which is essential for individuals to successfully challenge and change maladaptive thoughts with adaptive thinking. The inventory was designed to measure three aspects of cognitive flexibility: "(a) the tendency to perceive difficult situations as controllable; (b) the ability to perceive multiple alternative explanations for life occurrences and human behavior; and (c) the ability to generate multiple alternative solutions to difficult situations." (Dennis \& Vander Wal, 2010, p. 241). The scale includes 20 items with 10 items belong to alternatives subscale and 10 items belong to control subscale. A sample item of alternatives is "It is important to look at difficult situations from many angles" and an example of control is "I am capable of overcoming the difficulties in life that I face". The scale is suitable to calculate a unidimensional score as cognitive flexibility. High scores indicate high cognitive flexibility. Turkish Culture adaptation study of the scale was done by Gülüm and Dağ (2012). According to the findings of confirmatory factor analysis, two-factor structure (cognitive alternatives and control) of the scale has same psychometric properties as in its original form. Internal consistency coefficients were found as .90 for alternatives, .89 for control and .85 for total. In the current research, Cronbach's alpha coefficient was calculated as .82 for total scale.

\section{Self-Efficacy Questionnaire for Children (SEQ-C)}

SEQ-C was developed by Muris (2001) in order to measure academic, social and emotional self-efficacy of adolescents aged 14-17 years. The questionnaire contains 21 items that represents three sub-dimensions of self-efficacy: social, academic and emotional self-efficacy. Each item has to be scored on a 5-point scale. Turkish Culture adaptation study of the scale was conducted by Telef and Karaca (2012). Confirmatory factor analysis indicated that three-factor model fitted the research data. Internal reliability, test-retest reliability, item analysis, criterion-related validity analysis has demonstrated its reliability and validity. In the current study, Cronbach's alpha coefficient was calculated as .79 for academic self-efficacy, .71 for social self-efficacy, .75 for emotional self-efficacy, and .85 for total.

\section{Warwick Edinburgh Mental Well-Being Scale (WEMWBS)}

The scale was developed by Tennant et al. (2007) to measure mental well-being of individuals in UK. The scale consists of 14 positive items. High scores on the scale are in- dicative of high mental well-being. Confirmatory factor analysis supported the single factor hypothesis. Cronbach's alpha of internal consistency reliability coefficient of the scale was calculated as. 89 (student sample) and as .91 (population sample). WEMWBS showed high correlations with other mental health and well-being scales and lower correlations with scales measuring overall health (Tennant et al., 2007). Some statements of the scale are "I've been dealing with problems well" and "I've been feeling relaxed". Mc Kay and Andretta (2017) conducted validity and reliability of the scale on 2721 adolescents and they found that the scores were psychometrically valid and internally consistent. The adaptation of the scale into Turkish Culture was carried out by Keldal (2015). The values CFA were found to be $\chi^{2} / \mathrm{sd}=$ $3.71, \mathrm{RMR}=.05, \mathrm{NNFI}=.95, \mathrm{RFI}=.93, \mathrm{CFI}=.96$. The Cronbach's alpha coefficient of the scale was calculated as .92. As a result of the item analysis, it was revealed that the factor loadings of the scale items changed between .55 and .82. According to the results of the analysis, it was concluded that it is a valid and reliable scale assessing mental well-being in Turkish Culture (Keldal, 2015). Cronbach's alpha coefficient was calculated as .85 for the current sample.

\section{Statistical Analysis}

Descriptive statistics, Pearson's correlation method, an approach based on Ordinary Least Squares Regression and Bootstrapping were used in the analyses of the data. Mahalanobis distance values have been calculated in order to determine any outliers in the data. 2 participants were removed from the data set and the analyses were continued through 390 observations. The values of kurtosis and skewness were calculated in order to check normality of the data. Because the values of skewness and kurtosis range between +1 and -1 (Table 1) the data has been considered to have a normal distribution (Tabachnick \& Fidell, 2013). According to Hayes (2009) "if zero is not between the lower and upper bound, then the analyst can claim that the indirect effect is not zero with ci\% confidence." (p. 412). Accordingly, the point estimate is interpreted as a statistically significant variable that is not found in the zero range. In addition, contrast test was used in order to determine specific indirect of the variables and stronger mediators in the model. The Bootstrapping analyses of the study were conducted in parallel multiple mediation using "Multiple Mediation Model 4" through PROCESS Macro 3 using IBM SPSS, developed by Hayes $(2012,2017)$. Significance level in the study was accepted as .05. The data was analyzed through IBM SPSS 24.0 package program. 


\section{Results}

\section{Descriptives and Correlations}

Pearson's correlation coefficents were calculated to determine the relationships among the variables. Means, standard deviations, and correlations are presented in Table 1.

As presented in Table 1, cognitive flexibility correlated positively with self-efficacy sub-dimensions and mental well- being. Also, self-efficacy sub-dimensions positively correlated with mental well-being.

\section{Mediation Analyses}

The findings of the tested model of the parallel mediating roles of academic self-efficacy, social self-efficacy and emotional self-efficacy in the relationship between cognitive flexibility and mental well-being are presented in Figure 2.

Table 1. Descriptive Statistics and Pearson Correlation Coefficients Related to Research Variables.

\begin{tabular}{|c|c|c|c|c|c|c|c|c|c|}
\hline Variables & Mean & $S D$ & Skew & Kur & 1 & 2 & 3 & 4 & 5 \\
\hline 1.Cognitive Flexibility & 81.29 & .71 & -.00 & -.10 & -- & & & & \\
\hline 2.Academic Self-Efficacy & 20.28 & .28 & -.01 & -.32 & $.27 * *$ & -- & & & \\
\hline 3.Social Self-Efficacy & 23.36 & .26 & -.11 & -.22 & $.36^{* *}$ & $.34 * *$ & -- & & \\
\hline 4. Emotional Self-Efficacy & 20.57 & .29 & -.07 & -.51 & $.40^{* *}$ & $.50^{* *}$ & $.40^{* *}$ & -- & \\
\hline 5. Mental Well-Being & 49.59 & .55 & -.48 & .14 & $.47 * *$ & $.52^{* *}$ & $.57 * *$ & $.59 * *$ & -- \\
\hline
\end{tabular}

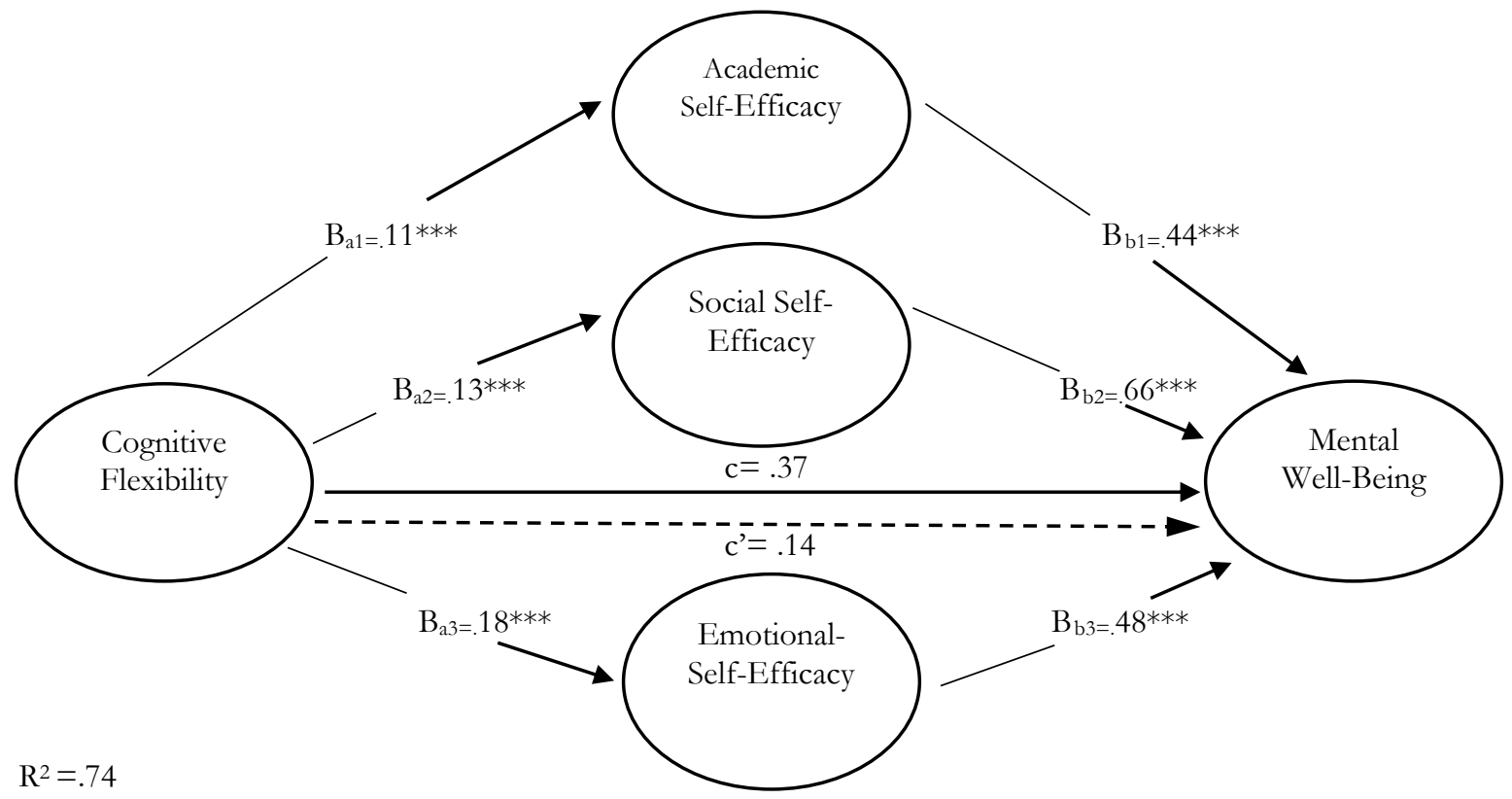

Figure 2. Parallel-Multiple Mediation of Self-Efficacy between Cognitive Flexibility and Mental Well-Being. Values.

$$
* * * p<.001
$$

As presented in Figure 1, the total effect of cognitive flexibility on mental well-being was statistically significant (c $=.37, \mathrm{SE}=.03, t=10.93, p<.001)$ (Step 1). The direct effects of cognitive flexibility on academic self-efficacy $(\mathrm{B}=$ $.11, \mathrm{SE}=.01, t=5.81, p<.001)$, social self-efficacy ( $\mathrm{B}=$ $.13, \mathrm{SE}=.01, t=7.76, p<.001)$ and emotional self-efficacy $(\mathrm{B}=.18, \mathrm{SE}=.01, t=9.68, p<.001)$ were statistically significant (Step 2). The direct effects of academic self-efficacy $(\mathrm{B}=.44, \mathrm{SE}=.07, t=5.72, p<.001)$, social self-efficacy (B $=.66, \mathrm{SE}=.08, t=8.24, p<.001)$ and emotional selfefficacy $(\mathrm{B}=.48, \mathrm{SE}=.08, t=5.93, p<.001)$ on mental well-being were statistically significant (Step 3$)$. When cogni- tive flexibility and mediating variables (academic selfefficacy, social self-efficacy and emotional self-efficacy) were simultaneously entered in the model (Step 4), the direct effect of cognitive flexibility on mental well-being decreased but the significance level did not change $(\mathrm{B}=.14, \mathrm{SE}=.03, t$ $=4.80, p<.001)$. These results support that the mediational model was significant $\left(\mathrm{F}_{(5-386)}, p<.001\right)$ and explained $74 \%$ of the variance in mental well-being. The comparison of indirect effects of cognitive flexibility through self-efficacy on mental well-being and their specific indirect effects are presented in Table 2. 
Table 2. Comparison of the Indirect Effects of Cognitive Flexibility on Mental Well-Being through Self-Efficacy.

\begin{tabular}{|c|c|c|c|c|c|c|}
\hline \multirow[b]{2}{*}{ Effects } & \multirow[b]{2}{*}{ Point Estimate } & \multirow[b]{2}{*}{$\mathrm{SE}$} & \multicolumn{2}{|c|}{ Product of Coefficients } & \multicolumn{2}{|c|}{ Boostrapping 95\% BCa Confidence Interval } \\
\hline & & & $\mathrm{z}$ & $p$ & Lower & Upper \\
\hline Total Indirect Effects & .2307 & .0270 & & & .1787 & .2853 \\
\hline Academic Self-Efficacy & .0507 & .0125 & 4.0517 & .0001 & .0275 & .0793 \\
\hline Social Self-Efficacy & .0918 & .0163 & 5.6313 & .0000 & .0607 & .1278 \\
\hline Emotional Self-Efficacy & .0882 & .0175 & 5.0412 & .0000 & .0559 & .1235 \\
\hline \multicolumn{7}{|l|}{ Contrasts } \\
\hline C1 & -.0412 & .0223 & & & -.0859 & .0013 \\
\hline C2 & -.0375 & .0216 & & & -.0786 & .0049 \\
\hline C3 & .0037 & .0246 & & & -.0433 & .0527 \\
\hline
\end{tabular}

Indirect Effects of Cognitive Flexibility on Mental Well-Being Through Self-Efficacy

The indirect effects were tested using bootsrapping with 5000 samples. Estimates were taken within 95\% confidence interval and bias corrected and accelerated results are presented in Table 2. As seen in Table 2, the total indirect effect (the difference between the total and indirect effects /c-c') of cognitive flexibility on mental well-being through academic self-efficacy, social self-efficacy and emotional self-efficacy is statistically significant (point estimate $=.2307$ and $95 \%$ BCa CI [.1787-.2853]. The mediators in the hypothetical model were examined separately. The findings revealed that the mediation of academic self-efficacy (point estimate= .0507 and $95 \%$ BCa CI [.0275, .0793], social self-efficacy (point estimate $=.0918$ and 95\% BCa CI [.0607, .1278] and emotional self-efficacy (point estimate $=.0882$ and $95 \% \mathrm{BCa}$ CI [.0559, .1235] were found statistically significant. In order to determine the powers of mediating variables, paired comparisons were conducted. As presented in Table 2, three comparisons were not found statistically significant which means that the mediating variables had no differences in terms of mediation power.

\section{Discussion and Conclusion}

Study findings have shown that the parallel mediating roles of academic-social-emotional self-efficacy are statistically significant in the model. It has been also found that the mediational hypothetical model has significant levels and approximately $74 \%$ of the variance in mental well-being $\left(R^{2}=.74\right)$. According to the findings of model contrasts, the mediating variables had no differences in terms of mediation power.

\section{Cognitive Flexibility and Mental Well-Being}

Consistent with prior research, cognitive flexibility has been found to be associated with mental well-being in this study. Cognitively flexible individuals are good at considering and employing a variety of coping strategies in order to solve problems and decrease distress (Johnson, 2016). The find- ings of the previous studies indicate that cognitively flexible adolescents are more extroverted, more self-controlled and more openness for improvement and likely to use problem focused coping strategies (Bilgin, 2017; Zhang, 2011). These characteristics are effective in protecting them from stress and negative experiences. Furthermore, the research of Asic1 and İkiz (2015) showed that the level of cognitive flexibility of university students predicts their happiness well. Fu and Chow (2017) reported that cognitively flexible adolescents who had an earthquake experience may tolerate better uncertainty of life, and think in a constructive way about the earthquake experience, deal with challenges in an effective way and all these process promote their psychological wellbeing. In a study by Al Jabari (2012), cognitive flexibility has been found negatively correlated with psychological symptoms. The current research is consistent with the prior findings implying cognitively flexible people who are aware of the cognitive alternatives and perceive difficult situations as controllable, challenge in a successful way and change maladaptive thoughts with adaptive thinking have better wellbeing (Dennis \& Vander Wal, 2010; Gabrys, Tabri, Anisman, \& Matheson, 2018).

Although some empirical studies indicated that adolescence should not be defined as a period of confusion as the greater number of adolescents manage this transition without excessive disturbance (Bandura, 1997; Offer \& SchonertReichl, 1992), adolescence period is generally considered as a critical period of development that is usually characterized by a great of stress resulting from many changes (FigueiraMcDonough, 1998; Rudolph, 2002). Individual differences in cognitive flexibility seem to be important in adolescents' healthy development. Bedel and Ulubey (2015) reported that cognitive flexibility positively correlated with active coping strategies of adolescents. Martin, Staggers and Anderson (2011) also demonstrated that cognitive flexibility was associated with higher intellectual flexibility and self-compassion. Cognitive flexibility reduces the impact of negative experiences by allowing an individual to generate ideas and consider alternatives in adapting to environmental changes (Hirt et al., 2008; Johnson, 2016). In an experimental study on adolescents, cognitive flexibility psycho-educational program has been found to be effective on positive coping strategies in- 
cluding self-confidence and optimism (Altunkol, 2017). It was also reported that the perceived stress level of the participants in experimental group decreased compared to control group. In another experimental study conducted by Johnco, Wuthrich and Rapee (2014) in 44 elderly subjects, the role of cognitive flexibility in the treatment of anxiety and depression through cognitive behavioral interventions was examined. Participants with high levels of cognitive flexibility found their cognitive restructuring skills more effective in reducing emotional stress compared to the participants with low level of cognitive flexibility. Timarova and Salaets (2011) also found, in an experimental study, that increased cognitive flexibility of college students was related to lower levels of anxiety, higher levels of motivation and success in training programs. The advantage of well-being in cognitively flexible people may be considered a function of their flexible thinking style.

\section{The Mediating Role of Self-Efficacy}

Consistent with previous findings the current research has revealed that cognitive flexibility predicts academic, social and emotional self-efficacy of adolescents (Akçay-Özcan \& Kıran-Esen, 2016; Çelikkaleli, 2014; Kaptanbaş-Gürbüz \& Sezgin-Nartgün, 2018). Self-efficacy is a core component of cognitive flexibility because the people need to believe that they have self-confident in producing the desired behaviour even if they are aware the alternative choices and willing to be flexible (Martin \& Anderson, 1998). According to Social Cognitive Theory (Bandura, 1986), the behaviour of an individual is constantly under the influence of cognitive factors. Research has provided evidence for perceived control as a cognitive factor is closely associated to self-efficacy beliefs (Zimmerman, 2000). Cognitive flexibility has an important role on academic, social and emotional self-efficacy of adolescents. Önen and Koçak (2015) demonstrated, on a sample of high school students, that cognitive flexibility correlated positively with positive attitudes towards studying, especially being eager to study. In a study by Stevens (2009) it was reported that cognitively flexible children were more likely to have better social skills, and less likely to display externalizing behaviors. The findings of a study by Vitiello, Greenfield, Munis and George (2011) suggest that the effect of cognitive flexibility on school readiness may be related to cognitive flexibility supporting children's approaches to learning. In another study, adolescents with higher cognitive flexibility were found to be more likely to use rational decision making strategies (Bilgiç, 2015). In a study by Bing (2011) cognitive flexibility could predict school adaptation well. Cognitive flexibility seems to enable greater success in achieving desired goals (Tamir, 2009). Cognitively flexible adolescents are aware of the alternative study strategies, rational decision making style and problem focused coping strategies that they can use in academic settings, so these characteristics allow them to feel competence in achieving both academic tasks and social demands (Bilgiç \& Bilgin, 2016; Önen \& Koçak,
2015; Zhang, 2011). The individuals with high cognitive flexibility have also social self-efficacy because they are willing to encounter unfamiliar situations, to seek new ways of communicating and to adjust behaviours to receive contextual needs (Martin \& Anderson, 1998). A recent research report has also indicated that cognitive flexibility is positively associated with emotion regulation and adaptive functioning (Singh, 2016). The study by Ahn et al. (2008), confirms the relationship between cognitive flexible and social selfefficacy that suggests children who have increased flexibility in solving problems may be able to create more alternatives in coping with conflicts between themselves and their parents. It has also been demonstrated on Turkish college students sample that social self-efficacy is important variable for well-being of students (Özbay, Palanc1, Kandemir, \& Çakır, 2012). Similarly, a previous study by Johnson (2016) suggests that the ability to consider alternatives and view situations as controllable enables the use of direct, pragmatic strategies to overcome challenges. An experimental study by Hyun, Chung and Lee (2005), designed to improve cognitive flexibility of adolescents, showed that cognitive-behavioral therapy program was effective in improving self-efficacy and decreasing the depression of adolescents. Based on these studies, it could be concluded that cognitively flexible adolescents view themselves as competent to achieve a specific academic goal, to deal with social interactions and to cope with negative emotions effectively.

The present study confirms previous findings reporting that self-efficacy beliefs contribute to one's psychological and psychosocial well-being (Bandura, 1990, 1997). Selfefficacy is essential to healthy development in adolescence (Phillips \& Zimmerman, 1990). Adolescents are faced with external and internal stress factors in this developmental stage such as transition to high school, achievement expectations of teachers and parents, growing need for autonomy and physical and cognitive changes. Thus, it is indispensable for an adolescent to keep confidence in the ability to control the challenging factors. Bandura (1997) implied that the positive effects of self-efficacy provide individuals to cope with stress. Self-efficacy beliefs also help individuals figure out success scenarios that allow positive guides for performance (Bandura, 1990). In regard to academic self-efficacy, the students who feel competent to accomplish academic task, study hard, carry on when they encounter difficulties. These characteristics have an effect on keeping them out of stress and negative experiences at school. Emotional self-efficacy beliefs provide the adolescents to regulate their emotional reactions. This is supported by the longitudinal study of Caprara et al. (2006) which indicated that adolescents' affective and social self-efficacy beliefs to manage positive and negative emotions contribute to their positive emotions and life satisfaction. In conjuction with this, Tommasi et al. (2018) reported that affective self-efficacy beliefs have predictive role on psychological well-being of adolescents. Moreover, a previous study by Muris (2002) demonstrated that individuals with high emotional self-efficacy are likely to 
have low level of depression and anxiety symptoms. Social self-efficacy beliefs enhance healthy development, social adjustment and functioning during adolescence (Armum \& Chellappan, 2016; Connolly, 1989). Interpersonal relationships play a vital role in complex transitional states characterizing adolescence (Caprara et al., 2006). Mcfarlane, Bellissimo and Norman (1995) reported that social self-efficacy negatively associated with depression in adolescents and, therefore, acts as protective factor. Based on these findings, it is not suprising to find out that self-efficacy beliefs promote adolescents' mental well-being.

\section{Limitations}

Although the study has carried out its aims, it has a limitation about the participants as they were chosen through convenience sampling method and consisted of high school students attending the schools in a city of Turkey. Adolescents from different schools, cities or regions would have increased the generalizability of the research findings. The other limitation of the research is cross-sectional nature of the data. While the models indicate potential directions of the relationships between the variables, causality cannot be deter-

\section{References}

Ahn, A. J., Kim, B. S. K., \& Park, Y. S. (2008). Asian cultural values gap, cognitive flexibility, coping strategies, and parent-child conflicts among Korean Americans. Cultural Diversity and Ethnic Minority Psychology, 14(4), 353-363. doi: 10.1037/1099-9809.14.4.353

Akçay-Özcan, D., \& Kıran-Esen, B. (2016). The investigation of adolescents' cognitive flexibility and self efficacy. International Journal Of Eurasia Social Sciences, 7(24), 1-10.

Al Jabari, R. M. (2012). Relationships among self-esteem, cognitive and psychological flexibility, and psychological symptomatology (Master Thesis). Retriewed from https://digital.library.unt.edu/ark:/67531/metadc177172/m2/1/high_ res_d/thesis.pdf

Altunkol, F. (2017). The effects of a cognitive flexibility education program on bigh school students' cognitive flexibility, perceived stress levels and coping styles (Doctoral dissertation). Cukurova University, Turkey. Retriewed from https://tez.yok.gov.tr/UlusalTezMerkezi/tezSorguSonucYeni.jsp.

Armum, P., \& Chellappan, K. (2016). Social and emotional self-efficacy of adolescents: measured and analysed interdependencies within and across academic achievement level. International Journal of Adolescence and Youth, 21(3), 279-288. doi: 10.1080/02673843.2015.1067894

Arslan, G. (2018). Psychological maltreatment, social acceptance, social connectedness, and subjective well-being in adolescents. Journal of Happiness Studies, 19, 983-1001. doi: 10.1007/s10902-017-9856-Z

Asıc1, E. \& İkiz, F. (2015). A pathway to happiness: Cognitive flexibility. Mehmet Akif Ersoy University Educational Faculty Journal, 1(35), 191-211.

Bandura, A. (1977). Social learning theory. Englewood Cliffs, NJ: Prentice Hall.

Bandura, A. (1986). Social foundations of thought and action: A social cognitive theory. Englewood Cliffs, NJ: Prentice-Hall.

Bandura, A. (1990). Perceived self-efficacy in the exercise of personal agency. Revista Española de Pedagogía, 48(187), 397-427.

Bandura, A. (1994). Self-efficacy. In V. S. Ramachaudran (Ed.), Encyclopedia of buman behavior (Vol. 4, pp. 71-81). New York: Academic Press. (Reprinted in H. Friedman [Ed.], Encyclopedia of mental health. San Diego: Academic Press, 1998).

Bandura, A. (1997). Self-efficacy: The exercise of control. New York: Freeman. mined. Future research will therefore need to involve longitudinal and experiemental studies in order to investigate complex causal relationships.

\section{Implications}

Regardless of this limitation, the present research contributes to the understanding the mental well-being of adolescents considering the influence of cognitive flexibility, academic, social and emotional self-efficacy on this positive construct. Findings obtained from this study may be used as future studies for various age groups and relationship types as well as for preventive counseling and guidance programs. Furthermore, the findings of the research have practical implications for well-being promotion, suggesting that interventions focused on cognitive flexibility will improve selfefficacy and mental well-being. Thus, the study has the potential to provide useful insight for further research and for professionals working within the field.

Note: The summary of this research study was presented in 20th International Psychological Counseling and Guidance Congress, 2528 October, 2018, Samsun, Turkey.

Bandura, A. (1999). A social cognitive theory of personality. In L. Pervin \& O. John (Ed.), Handbook of personality (2nd ed., pp. 154-196). New York: Guilford Publications.

Bandura, A., Barbaranelli, C., Caprara, G. V., \& Pastorelli, C. (1996). Multifaceted impact of self-efficacy beliefs on academic functioning. Child Development, 67, 1206-1222.

Bandura, A., Pastorelli, C., Barbaranelli, C., \& Caprara, G. V. (1999). Selfefficacy pathways to childhood depression. Journal of Personality and Social Psychology, 76(2), 258-269. doi: 10.1037/0022-3514.76.2.258

Bandura, A., Caprara, G. V., Barbaranelli, C., Gerbino, M., \& Pastorelli, C. (2003). Role of affective self-regulatory efficacy in diverse spheres of psychosocial functioning. Child Development, 74(3), 769-782.

Bedel, A., \& Ulubey, E. (2015). The role of cognitive flexibility on explanation adolescents coping strategies. Electronic Journal of Social Sciences, 14(55), 291-300.

Baytemir, K. (2016). The mediation of interpersonal competence in the relationship between parent and peer attachment and subjective wellbeing in adolescence. Education and Science, 41(186), 69-91.

Bilgiç, R. (2015). Analysis of the relationship betwen the cognitive flexibility levels and decision strategies in adolescents based on sex and education level (Master's thesis). Çukurova University, Turkey. Retriewed from https://tez.yok.gov.tr/UlusalTezMerkezi/tezSorguSonucYeni.jsp

Bilgiç, R., \& Bilgin, M. (2016). Analysis of the relationship between the cognitive flexibility levels and decision strategies in adolescents based on sex and education level. Uşak. University Educational Research Journal, 2(2), 39-55.

Bilgin, M. (2017). Relations to five factor personality model with cognitive flexibility in adolescents. Electronic Journal of Social Sciences, 16(62), 945954.

Bing, Z. (2011). A relationship study on cognitive flexibility and school adaptation for the freshmen (Master's Thesis). Hebei University, China. Retriewed from https://search.proquest.com/pqdtglobal/docview/1874542152/A765 8266AA6D4846PQ/1?accountid $=11054$

Bloom, J. R., Stewart, S. L., Johnston, M., Banks, P., Fobair, P. (2001). Sources of support and the physical and mental well-being of young women with breast cancer. Social Science \& Medicine, 53, 1512-1524. 
Caprara, G.V., Regalia, C., \& Bandura, A. (2002). Longitudinal impact of perceived self-regulatory efficacy on violent conduct. European Psychologist, 7, 63-69.

Caprara, G. V.,, Steca, P., Gerbino, M., Pacielloi, M., \& Vecchio, G. M. (2006). Looking for adolescents' well-being: self-efficacy beliefs as determinants of positive thinking and happiness. Epidemiol Psichiatr Soc., 15(1), 30-43.

Cicchetti, D., \& Rogosch, F. A. (2002). A developmental psychopathology perspective on adolescence. Journal of Consulting and Clinical Psychology, 70(1), 6-20. doi: 10.1037/0022-006X.70.1.6

Cicognani, E. (2011). Coping strategies with minor stressors in adolescence: relationships with social support, self-efficacy, and psychological wellbeing. Journal of Applied Social Psychology, 41(3), 559-578.

Cohen, L., Manion, L., \& Morrison, K. (2011). Research methods in education ( $7^{\text {th }}$ ed.). London: Routledge.

Connolly, J. (1989). Social self-efficacy in adolescence: Relations with selfconcept, social adjustment, and mental health. Canadian Journal of Behavioural Science , 21(3), 258-269. doi: 10.1037/h0079809

Çakar, F. S., \& Tagay, Ö. (2015). The mediating role of self-esteem: The effects of social support and subjective well-being on adolescents' risky behaviors. Educational Sciences: Theory \& Practice, 17, 859-876. doi: 10.12738/estp.2017.3.0024

Çelikkaleli, Ö. (2014). The relation between cognitive flexibility and academic, socialand emotional self-efficacy beliefs among adolescents. Education and Science, 39(176), 347-354.

Çikrıkci, Ö. (2018). The predictive roles of cognitive flexibility and error oriented motivation skills on life satisfaction. International Journal of Eurasia Social Sciences, 9(31), 717-727.

De Dreu, C. K. W., Baas, M., \& Nijstad, B. A. (2008). Hedonic tone and activation in the mood-creativity link: Towards a dual pathway to creativity model. Journal of Personality and Social Psychology, 94, 739-756.

Demirtaş, A. S., Baytemir, K., \& Güllü, A. (2017). Hope and mental wellbeing in pedagogy formation students: The mediating role of constructive thinking. Mersin University Journal of the Faculty of Education, 14(1), 317-331. doi: 10.17860/mersinefd.354636

Dennis, J. P., \& Vander Wal, J. S. (2010). The Cognitive Flexibility Inventory: Instrument development and estimates of reliability and validity. Cognitive Therapy and Research, 34, 241-253. doi:10.1007/s10608-0099276-4

Diener, E (1984). Subjective well-being. Psychol Bull, 95(3), 542-75.

Duy, B., \& Ylldiz, M. A. (2017). The mediating role of self-esteem in the relationship between optimism and subjective well-being, Current Psycho$\log$, doi: $10.1007 / \mathrm{s} 12144-017-9698-1$

Eryılmaz, A., \& Öğ̈̈lmüş, S. (2010). Ergenlikte öznel iyi oluş ve beş faktörlü kişilik modeli Abi Evran Üniversitesi Eğitim Fakültesi Dergisi, 11(3), 189-203.

Figueira-McDonough, J. (1998). Environment and interpretation: Voices of young people in poor inner-city neighborhoods. Youth \& Society, 30(2), 123-163.

Fraenkel, J. R., Wallen, N. E., \& Hyun, H. H. (2012). How to design and evaluate research in education (8th ed.). New York, Mc Graw HIll.

Fu, F., \& Chow, A. (2016) Traumatic exposure and psychological wellbeing: The moderating role of cognitive flexibility. Journal of Loss and Trauma, 22(1), 24-35. doi: 10.1080/15325024.2016.1161428

Gabrys, R. L., Tabri, N., Anisman, H., \& Matheson, K. (2018). Cognitive Control and Flexibility in the Context of Stress and Depressive Symptoms: The Cognitive Control and Flexibility Questionnaire. Frontiers in Psychology, 9(2219), 1-19. http://dx.doi.org/10.3389/fpsyg.2018.02219

Gülüm, İ. V. \& Dağ, İ. (2012). The Turkish adaptation, validity and reliability study of the Repetitive Thinking Questionnaire and The Cognitive Flexibility Inventory. Anatolian Journal of Psychiatry, 13, 216-223.

Hayes, A. F. (2009): Beyond Baron and Kenny: Statistical mediation analysis in the new millennium. Communication Monographs, 76(4), 408-420. doi: $10.1080 / 03637750903310360$

Hayes, A. F. (2012). Process: A versatile computational tool for observed variable mediation, moderation, and conditional process modeling. Retrieved from www.processmacro.org/download.html
Hayes, A. F. (2017). Introduction to mediation, moderation, and conditional process analysis: A regression-based approach. Second Edition. New York: Guilford Press

Hayes, S. C., Luoma, J. B., Bond, F. W., Masuda, A., Lillis, J. (2006). Acceptance and commitment therapy: Model, processes, and outcomes. Behaviour Research and Therapy, 44, 1-25.

Hermann, K. S., \& Betz, N. E. (2004). Path models of the relationships of instrumentality and expressiveness to social self-efficacy, shyness, and depressive symptoms. Sex Roles, 51, 55-67.

Hirt, E. R., Devers, E. E., \& McCrea, S. M. (2008). I want to be creative: Exploring the role of hedonic contingency theory in the positive mood-cognitive flexibility link. Journal of Personality and Social Psychology, 94, 214-230.

Huppert, F., \& Whittington, J. (2003). Evidence for the independence of positive and negative well-being: Implications for quality of life assessment. British Journal of Health Psychology, 8, 107-122. doi: 10.1348/135910703762879246

Hyun, M., Chung, H., \& Lee, Y. (2005). The effect of cognitive-behavioral group therapy on the self-esteem, depression, and self-efficacy of runaway adolescents in a shelter in South Korea, Applied Nursing Research, 18(3), doi: 10.1016/j.apnr.2004.07.006

Imtiaz, S., \& Kamal, A. (2016). Rumination, optimism, and psychological well-being among the elderly: Self-compassion as a predictor. Journal of Behavioural Sciences, 26(1), 32- 50

Johnco, C., Wuthrich V. M., \& Rapee, R. M. (2014). The influence of cognitive flexibility on treatment outcome and cognitive restructuring skill acquisition during cognitive behavioural treatment for anxiety and depression in older adults: Results of a pilot study. Behaviour Research and Therapy, 57, 55-64.

Johnson, B. T. (2016). The relationship between cognitive flexibility, coping, and symptomatology in psychotherapy (Master's Thesis). Faculty of the Graduate School, Marquette University, Wisconsin. Retrieved from https://search.proquest.com/pqdtglobal/docview/1784011416/fulltex tPDF/C30DC2A5C82D4DD8PQ/1 ?accountid=11054

Kaptanbaş-Gürbüz, E., \& Sezgin-Nartgün, S.. (2018). Cognitive flexibility and self-efficacy levels of pedagogical formation program students. The Journal of International Social Research, 11(55), 628-640.

Kato, T. (2012). Development of the Coping Flexibility Scale: Evidence for the coping flexibility hypothesis. Journal of Counseling Psychology, 14(4), 353-363. doi: $0.1037 / \mathrm{a} 0027770$

Keldal, G. (2015). Turkish Version of the Warwick-Edinburgh Mental WellBeing Scale: A validity and reliability study. The Journal of Happiness and Well-Being, 3(1), 103-115.

Keyes, C. L. (2005). Mental illness and/or mental health? Investigating axioms of the complete state model of health. Journal of Consulting and Clinical Psychology, 73, 539-548.

Khallad, Y., \& Jabr, F. (2016). Effects of perceived social support and family demands on college students' mental well-being: A cross-cultural investigation. International Journal of Psychology, 51(5), 348-355. doi: 10.1002/ijop.12177

Li, T., \& Feng, F. (2018). Goal content, well-being, and psychological needs satisfaction in Chinese adolescents. Social Behavior and Personality: An international journal, 46, 541-550. doi: 10.2224/sbp.6831

Lin, Y. (2013). The effects of cognitive flexibility and openness to change on college students' academic performance (Master's thesis). Hebei University, China. Retriewed

from https://search.proquest.com/pqdtglobal/docview/1433926373/fulltex tPDF/48733DBA637946A4PQ/1? accountid=11054

López, M., Gabilondo, A., Codony, M., García-Forero, C., Vilagut, G., Castellví, P., Ferrer, M., \& Alonso, J. (2013). Adaptation into Spanish of the Warwick Edinburgh Mental Well- Being Scale (WEMWBS) and preliminary validation in a student sample. Quality of Life Research, 22, 1099-1104.

Ma, Z., Zeng, W., \& Ye, K. (2015). Gender differences in Chinese adolescents' subjective well-being: The mediating role of self-efficacy. Psychological Reports: Sociocultural Issues in Psychology, 116(1), 311-321.

Martin, M. \& Anderson, C. (1998). The Cognitive Flexibility Scale: three validity studies. Communication Reports, 11, 1-9. doi: 10.1080/08934219809367680. 
Martin, M. M., \& Rubin, R. B. (1995). A new measure of cognitive flexibility. Psychological Reports, 76, 623-62.

Martin, M. M., Staggers, S. M., \& Anderson, C. M. (2011) The relationships between cognitive flexibility with dogmatism, intellectual flexibility, preference for consistency, and self-compassion, Communication Research Reports, 28(3), 275-280. doi: 10.1080/08824096.2011.587555

McGeown, S. P., Putwain, D., Geijer Simpson, E., Boffey, E., Markham, J., \& Vince, A. (2014). Predictors of adolescents' academic motivation: Personality, self-efficacy and adolescents' characteristics. Learning and Individual Differences, 32, 278-286. doi: 10.1016/j.lindif.2014.03.022

McFarlane, A. H., Bellissimo, A., \& Norman, G. R. (1995). The role of family and peers in social self-efficacy: Links to depression in adolescence. American Journal of Orthopsychiatry, 65(3), 402-410. doi: 10.1037/h0079655

McKay, M. T., \& Andretta, J. R. (2017). Evidence for the psychometric validity, internal consistency and measurement invariance of Warwick Edinburgh Mental Well-being Scale scores in Scottish and Irish adolescents. Pyschiatry Research, 255, 382-386. doi: 10.1016/j.psychres.2017.06.071

Meyer, B., \& Kim, U. (2000). The inter-relationships among German adolescents' selfefficacy, perception of home and school environment, and health. Poster presented at the 15th International Congress of the International Association for Cross Cultural Psychology (IACCP), Pultusk, Poland.

Mischel, W., \& Shoda, Y. (1995). A cognitive-affective system theory of personality: Reconceptualizing situations, dispositions, dynamics, and invariance in personality structure. Psychological Review, 102(2), 246-268. doi.org: 10.1037/0033-295X.102.2.246

Moeini, B., Shafii, F., Hidarnia, A., Babaii, G., Birashk, B., \& Allahverdipour, H. (2008). Perceived stress, self-efficacy and its relations to psychological wellbeing status in Iranian male high school students. Social Behavior and Personality: An International Journal, 36, 257-266. doi: 10.2224/sbp.2008.36.2.257

Morrish, L., Rickard, N., Chin, T. C., \& Vella-Brodrick, D. A. (2018). Emotion regulation in adolescent well-being and positive education. Journal of Happiness Studies, 19 (5), 1543-1564.

Muris, P. (2001). A brief questionnaire for measuring self-efficacy in youths. Journal of Psychopathology and Behavioral Assessment, 23(3), 145-149. doi: 10.1023/A:1010961119608

Muris, P. (2002). Relationships between self-efficacy and symptoms of anxiety disorders and depression in a normal adolescent sample. Personality and Individual Differences, 32, 337-348.

Nordentoft, M. (2007). Prevention of suicide and attempted suicide in Denmark. Epidemiological studies of suicide and intervention studies in selected risk groups. Danish Medical Bulletin, 4, 306-69.

Offer, D. \& Schonert-Reichl, K. A. (1992) Debunking three myths of adolescence: findings from recent research. Journal of the American Academy of Child Adolescent Psychiatry, 31, 1003-1014.

Önen, A. S., \& Koçak, C. (2015). The Effect of Cognitive Flexibility on Higher School Students' Study Strategies. Procedia - Social and Behavioral Sciences, 191(2), 2346-2350. doi: 10.1016/j.sbspro.2015.04.680

Özbay, Y., Palancı, M., Kandemir, M. \& Çakır, O. (2012). Prediction of subjective well-being of university students via self regulation, humour, social selfefficacy ans stress coping strategies. The Journal of Turkish Educational Sciences, 10(2), 341-345.

Pajares, F. (1996). Self-efficacy beliefs in achievement settings. Review of Educational Research, 66, 543-578.

Phillips, D. A., \& Zimmerman, M. (1990). The developmental course of perceived competence and incompetence among competent children. In R. J. Sternberg \& J. Kolligian, Jr. (Eds.), Competence considered (pp. 41-66). New Haven, CT, US: Yale University Press.

Rudolf, K. D. (2002). Gender differences in emotional responses to interpersonal stress during adolescence. Journal of Adolescent Health, 30(4), 3-13. doi: 10.1016/S1054-139X(01)00383-4

Ryan, R. M., \& Deci, E. L. (2001). On happiness and human potentials: A review of research on hedonic and eudaimonic well-being. Annual Review of Psychology, 52(1), 141- 66. doi: 10.1146/annurev.psych.52.1.141

Ryff, C. D. (1989). Happiness is everything, or is it? Explorations on the meaning of psychological well-being. Journal of Personality and Social Psychology, 57, 1069-1081.
Singh, S. (2016). Does emotion regulation mediate the relationship between cognitive flexibility and adaptive functioning? (Master's thesis). Illinois Institute of Technology, USA. Retriewed from https://search.proquest.com/pqdtglobal/docview/1876538282/fulltextPD F/218EC99E7C745A6PQ/14?accountid=11054

Sheldon, K. M., Fredrickson, B., Rathunde, K., Csikszentmihalyi, M., \& Haidt, J. (2000). Positive psychology manifesto. Manifesto presented at Akumal 1 conference and revised during the Akumal 2 meeting. Retriewed from https://positivepsychology.org/akumalmanifesto.htm

Stewart-Brown, S., Tennant, A., Tennant, R., Platt, S., Parkinson, J., \& Weich, S. (2009). Internal construct validity of the Warwick-Edinburgh Mental Wellbeing Scale (WEMWBS): A Rasch analysis using data from the Scottish Health Education Population Survey. Health and Quality of Life Outcomes, 7 , $1-8$

Stevens, A. (2009). Social problem -solving and cognitive flexibility: Relations to social skills and problem behavior of at -risk young children (Doctoral dissertation). Seattle Pacific University, USA. Retriewed from https://search.proquest.com/pqdtglobal/docview/305138555/7DB86DA FA82544B8PQ/2? accountid $=11054$

Tabachnick, B.G., \& Fidell, L.S. (2013) Using Multivariate Statistics. Pearson, Boston.

Tamir, M. (2009) What do people want to feel and why? Pleasure and utility in emotion regulation. Current Directions in Psychological Science, 18, 101-105.

Taş, D., Öztürk-Çopur, E., Ünlü, H., Tüzün, Z., \& Özcebe, L. H. (2017). Quality of life and self-efficacy of adolescents with chronic health conditions. Dicle Medical Journal, 44(3), 257-265.

Telef, B. B., \& Ergün, E. (2013). Self-efficacy as a predictor of high school students' subjective well-being. Journal of Theoretical Educational Science, 6(3), $423-$ 433. doi: $10.5578 / \mathrm{keg} .5955$

Telef, B. B., \& Karaca, R. (2011). Adolescents's self-efficacy and psychological symptoms' investigation. Mustafa Kemal University Joumal of Social Sciences Institute, 8(16), 499-518.

Telef, B. B., \& Karaca, R. (2012). The Self-Efficacy Scale for Children: A validity and reliability study. Dokuz Eylül University Buca Education Faculty Journal, 32, $169-187$.

Tennant, R., Hiller, L., Fishwick, R., Platt, S., Joseph, S., Weich, S., Parkinson, J., Secker, J. ve Stewart-Brown, S. (2007). The Warwick-Edinburgh Mental Well-Being Scale (WEMWBS): Development and UK validation. Health and Quality of Life Outcomes, 5(1), 50-63. doi:10.1186/1477-7525-5-63

Timarova, S., \& Salaets, H. (2011). Learning styles, motivation and cognitive flexibility in interpreter training: Self-selection and aptitude. Interpreting, 13, 31 52.

Tommasi, M., Grassi, P., Balsamo, M., Picconi, L., Furnham, A., \& Saggino, A. (2018). Correlations between personality, affective and filial self-efficacy beliefs, and psychological well-being in a sample of Italian adolescents. Psychological Reports, 121(1), 59-78.

Yang, Y., Li, P., Fu, X., \& Kou, Y. (2017). Orientations to happiness and subjective well-being in Chinese adolescents: The roles of prosocial behavior and internet addictive behavior. Journal of Happiness Studies, 18(6), 1747-1762.

Yap, S. T., \& Baharudin, R. (2016). The relationship between adolescents' perceived parental involvement, self-efficacy beliefs, and subjective well-being: A multiple mediator model. Social Indicators Research, 126(1), 257-278.

You, S., Lim, S. S., \& Kim, E. K. (2018). Relationships between social support, internal assets, and life satisfaction in Korean adolescents. Journal of Happiness Studies, 19(3), 897-915.

Vitiello, V. E., Greenfield, D., Munis, P., \& George, JL. (2011). Cognitive flexibility, approaches to learning, and academic school readiness in head start preschool children. Early Education and Development, 22(3), 388-410. doi: 10.1080/10409289.2011.538366.

Zhang, J. H. (2011). Relationship between cognitive flexibility and coping strategies of high school students (Master's Thesis). Hebei University, China. Retriewed from https://search.proquest.com/pqdtglobal/docview/1874541120/107E707 AD3C54AB4PQ/ 1 ?accountid $=11054$

Zimmerman, B. J. (2000). Attainment of self-regulation: A social cognitive perspective. In M. Boekaerts, P.R. Pintrich, \& M. Zeidner (Eds.), Handbook of self-regulation (pp. 13-39). San Diego, CA: Academic Press. 